\title{
PENGARUH IRIGASI DAN MULSA ORGANIK TERHADAP PERTUMBUHAN TANAMAN NANAS (Ananas comosus) DI DAERAH TROPIKA BASAH
}

\author{
Ali Rahmat ${ }^{1}$, Afandi ${ }^{1}$, Tumiar K.B. Manik ${ }^{1}$ \& Priyo Cahyono ${ }^{2}$ \\ 'Jurusan Agroteknologi, Fakultas Pertanian Universitas Lampung \\ Jl. Prof. Soemantri Brodjonegoro, No. 1, Bandar Lampung 35145 \\ E-mail: Alyrahmat@yahoo.com \\ ${ }^{2}$ Staf Riset PT Great Giant Pineapple, Terbanggi Besar, Lampung Tengah
}

\begin{abstract}
ABSTRAK
Irigasi pada tanaman nanas sangat penting karena mempengaruhi pertumbuhan dan produksi terutama di daerah tropika basah, namun biaya untuk irigasi sangat mahal. Penelitian bertujuan untuk mengetahui pengaruh irigasi dan mulsa organik terhadap pertumbuhan tanaman nanas di daerah tropika basah. Penelitian dilakukan dengan rancangan perlakuan faktorial (5 $\mathrm{x} 2$ ) dalam rancangan acak kelompok dengan 3 kali ulangan. Faktor pertama adalah lama irigasi (I) yang terdiri dari 5 lama irigasi yaitu tanpa irigasi $\left(\mathrm{I}_{0}\right)$, diirigasi 1 bulan $\left(\mathrm{I}_{1}\right)$, diirigasi 2 bulan $\left(\mathrm{I}_{2}\right)$, diirigasi 3 bulan $\left(\mathrm{I}_{3}\right)$, dan diirigasi 4 bulan $\left(\mathrm{I}_{4}\right)$. Faktor yang kedua adalah dosis mulsa kulit singkong terdiri dari 2 taraf yaitu 0 t ha- ${ }^{-1}\left(\mathrm{M}_{0}\right)$ dan $50 \mathrm{t} \mathrm{ha}^{-1}\left(\mathrm{M}_{1}\right)$. Data pertumbuhan tanaman dianalisis ragam dan dilanjutkan dengan uji BNT pada taraf 5\%. Tinggi tanaman 6 BST perlakuan yang irigasi 4 bulan bermulsa dan tidak bermulsa tidak berbeda nyata, dengan tinggi tanaman tertinggi pada perlakuan $\mathrm{I}_{4} \mathrm{M}_{1}$ yaitu $80,39 \mathrm{~cm}$. Berat basah tanaman 4 BST yang irigasi 4 bulan bermulsa, irigasi 4 bulan tanpa mulsa dan irigasi 3 bulan bermulsa tidak berbeda nyata. Terjadi pemulihan keragaan tanaman terutama berat basah setelah memasuki musim hujan dimana kadar air tanah maksimum.
\end{abstract}

Kata Kunci: Iklim tropika basah, irigasi, kulit singkong, mulsa organik, nanas.

\section{PENDAHULUAN}

Nanas merupakan salah satu komoditas yang banyak ditanam di Indonesia. Prospek agribisnis nanas sangat cerah, karena adanya peningkatan permintaan baik untuk kebutuhan buah segar maupun sebagai bahan olahan. Nanas adalah komoditas hortikultura yang sangat potensial dan penting diperdagangan dunia. Produksi nanas di Indonesia pada tahun 2010 mencapai 1.406 .445 ton dan meningkat pada tahun 2011 menjadi 1.540 .626 ton (BPS, 2012), namun produksi tersebut belum cukup untuk memenuhi kebutuhan pasar dunia sehingga masih diperlukan adanya peningkatan produksi nanas.

Indonesia merupakan salah satu negara berilkim tropika basah dengan curah hujan rata-rata tahunan berkisar $2500 \mathrm{~mm}-3000 \mathrm{~mm}$, dengan suhu rata-rata disiang hari $32^{\circ} \mathrm{C}$ dengan kelembaban udara $80-90 \%$. Suhu Udara yang tinggi dan intensitas radiasi matahari yang tinggi di negara tropis menyebabkan penguapan yang tinggi (Ferraris, 1992). Pada musim kemarau ketersediaan air seringkali membatasi pertumbuhan dan perkembangan tanaman. Respon tumbuhan terhadap kekurangan air dapat dilihat pada aktivitas metabolisme, morfologi, tingkat pertumbuhan, atau produktivitasnya. Kekurangan air akan mempengaruhi turgor sel sehingga akan mengurangi pengembangan sel, sintesis protein, dan sintesis dinding sel (Gardner et al., 1991 dalam
Hutasoit, 2006). Oleh sebab itu irigasi merupakan salah satu faktor yang penting dalam peningkatan produksi karena irigasi bertujuan untuk memenuhi kebutuhan air agar tanaman dapat tumbuh dan berkembang dengan baik. Akan tetapi biaya irigasi secara intensif cukup mahal oleh sebab itu diperlukan teknologi untuk mempertahankan kadar air tanah agar tetap tinggi. Salah satu teknologi yang dapat digunakan untuk mempertahankan kadar air tanah adalah penggunaan mulsa dan irigasi yang efisien.

Menurut Komariah, et al. (2008), pemberian mulsa organik dapat meminimalkan evaporasi, meningkatkan kapasitas menahan air. Menurut Nasution (2000), pemberian mulsa berpengaruh nyata memperbaiki sifat fisik tanah, meningkatkan pertumbuhan dan produksi tanaman kedelai di tanah Alfisol. Menurut Surater, et al. (1986), pemberian mulsa jerami meningkat kan hasil umbi ketang secara nyata, peningkatan hasil terutama terjadi pada umbi besar dan sedang.

\section{BAHAN DAN METODE}

Penelitian ini dilaksanakan di Research Station PT Great Giant Pineapple lokasi 36H pada bulan Mei 2012 sampai dengan bulan Desember 2012 dengan posisi

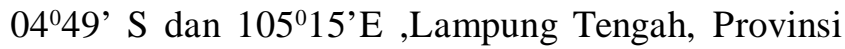


Lampung. Alat-alat yang digunakan dalam penelitian ini diantaranya adalah: timbangan, boom carts, cangkul, oven, Bahan yang digunakan dalam penelitian ini adalah: Mulsa kulit singkong, Air, Pupuk, pestisida, bibit nanas klon GP3 suker sedang dan sampel tanah.

Metode yang digunakan dalam Penelitian ini adalah Rancang acak kelompok (RAK) dengan 2 faktor perlakuan yaitu 5 perbedaan intensitas waktu irigasi dan 2 taraf dosis mulsa serta diulangan 3 kali, total seluruh percobaan adala 30 satuan percobaan. Perlakuan yang diberikan adalah faktor lama irigasi $\mathrm{I}_{0}$ : tanpa irigasi, $\mathrm{I}_{1}$ : selama satu bulan diirigasi tiap 5 hari, kemudian bulan ke 2 dan seterusnya tidak diirigasi. $\mathrm{I}_{2}$ : Selama dua bulan diirigasi tiap 5 hari, kemudian bulan ke 3 dan seterusnya tidak diirigasi. $\mathrm{I}_{3}$ : Selama tiga bulan diirigasi tiap 5 hari kemudian bulan ke 4 dan seterusnya tidak diirigasi. $\mathrm{I}_{4}$ : Selama empat bulan diirigasi tiap 5 hari, kemudian tidak diirigasi. Faktor kedua mulsa organik berupa kulit singkong $\mathrm{M}_{0}$ : Tanpa mulsa organik, $\mathrm{M}_{1}$ : Mulsa Organik $50 \mathrm{tha}^{-1}$

Adapun variabel pengamatan pada penelitian ini adalah tinggi tanaman $(\mathrm{cm})$ dan berat basah tanaman (g). Persiapan lahan meliputi kegiatan pengolahan tanah dan pembuatan petak satuan percobaan. Lahan dibagi menjadi 30 petak percobaan sesuai dengan perlakuan, dan ukuran tiap petaknya $3 \mathrm{~m} \times 5 \mathrm{~m}$. Lahan yang digunakan bertekstur liat. Bibit nanas sucker sedang (tinggi 30-35 cm) klon GP3 ditanam dengan jarak tanam antar baris $60 \mathrm{~cm}$ dan antar tanaman $25 \mathrm{~cm}$. Dalam setiap petak terdapat 100 tanaman dan 20 tanaman sebagai sampel yang dipilih secara acak. Setelah itu dilakukan penyiraman pertama dengan boom carts hingga tanah jenuh air kira-kira dengan tebal siram 8,5 $\mathrm{mm}$. Kemudian diaplikasikan mulsa organik pada lahan dengan cara ditabur secara merata di atas permukaan tanah secara manual.

Data yang diperoleh diuji dengan menggunakan analisis ragam. Sebelum analisis ragam, homogenitas data diuji dengan uji barlet dan aditifitas data dengan uji tukey. Setelah itu dilakukan uji lanjut dengan uji Beda Nyata Terkecil (BNT) taraf $5 \%$.

\section{HASIL DAN PEMBAHASAN}

Pertumbuhan tanaman sering didefinisikan sebagai pertambahan ukuran, berat, volume dan jumlah sel. Pertumbuhan tanaman dapat dianalisis dari hasil pengamatan tinggi tanaman, jumlah daun, berat basah akar dan berat basah tanaman. Pertumbuhan tanaman di amati pada 4 bulan setelah tanam (BST) dan 6 bulan setelah tanam (BST). Tinggi tanaman nanas diukur berdasarkan daun tertinggi. Data pengaruh irigasi dan mulsa organik terhadap tinggi tanaman disajikan pada Tabel 1. dan Tabel 2. Pada Tinggi tanaman nanas 4 BST berdasarkan analisis ragam tinggi tanaman nanas 4 BST dipengaruhi oleh pemberian mulsa $50 \mathrm{t} \mathrm{ha}^{-1}$. Rata-rata tinggi tanaman pada perlakuan tanpa mulsa lebih tinggi $(61,98 \mathrm{~cm})$ di bandingkan dengan yang diberi mulsa $(60,96 \mathrm{~cm})$ namun tidak berbeda nyata, hal ini menunjukan pemberian mulsa tidak efektif dalam meningkatkan tinggi tanaman. Pada tinggi tanaman nanas 6 BST (Tabel 2) berdasarkan analisis ragam interaksi irigasi dengan mulsa organik berpengaruh terhadap tinggi tanaman. Perlakuan $\mathrm{I}_{4}$ (irigasi 4 bulan) dan $\mathrm{I}_{3}$ (irigasi 3 bulan) pada perlakuan tanpa mulsa tinggi tanamannya tidak berbeda nyata namun berbeda nyata dengan perlakuan irigasi yang lain.

Perlakuan $\mathrm{I}_{4}$ (irigasi 4 bulan) pada petak bermulsa tinggi tanaman nanas berbeda nyata dibandingkan dengan perlakuan irigasi yang lainnya. Sedangkan pada semua perlakuan irigasi tinggi tanaman pada petak yang diberi mulsa dan tidak diberi mulsa tidak berbeda nyata. Tinggi tanaman tertinggi pada perlakuan $\mathrm{I}_{4} \mathrm{M}_{1}$ (irigasi 4 bulan bermulsa) yaitu $80,39 \mathrm{~cm}$ namun tidak berbeda dengan $\mathrm{I}_{4} \mathrm{M}_{0}$ (irigasi 4 bulan tanpa mulsa) $78,26 \mathrm{~cm}$, sedangkan untuk tinggi tanaman terendah terdapat pada perlakuan $\mathrm{I}_{0} \mathrm{M}_{0}$ (tanpa irigasi tanpa mulsa) yaitu 66,68 $\mathrm{cm}$. Hal ini dapat terjadi dikarenakan dari awal tanam hingga akhir perlakuan pada perlakuan irigasi 4 bulan kebutuhan air bagi tanaman selalu tersedia sehingga tanaman dapat tumbuh dengan optimal, sedangkan pada perlakuan tanpa irigasi dari awal tanam hingga akhir perlakuan mengalami cekaman kekeringan dan air pada awal musim hujan belum dapat membantu dalam memulihan keragaaan tanaman tanaman.

Berat basah tanaman diperoleh dari menimbang semua bagiatan tanaman. Pengaruh irigasi dan mulsa organik terhadap berat basah tanaman nanas disajikan pada Tabel 3. Berdasarkan analisis ragam berat basah tanaman nanas 4 BST dipengaruhi oleh interaksi antara irigasi dengan mulsa. Perlakuan $\mathrm{I}_{4}$ (irigasi 4 bulan) dan $\mathrm{I}_{3}$ (irigasi 3 bulan) pada perlakuan tanpa mulsa

Tabel 1. Pengaruh irigasi dan mulsa organik terhadap tinggi tanaman nanas 4 BS

\begin{tabular}{cc}
\hline Perlakuan Mulsa Organik & Rataan $(\mathrm{cm})$ \\
\hline $\mathrm{M}_{0}$ & $61,98 \mathrm{a}$ \\
$\mathrm{M}_{1}$ & $60,96 \mathrm{a}$ \\
\hline $\mathrm{BNT}$ & 1,36 \\
\hline
\end{tabular}

Keterangan: Angka yang diikuti huruf yang sama pada kolom yang sama tidak berbeda nyata menurut uji BNT pada $\alpha_{0,05}$. 
Tabel 2. Pengaruh irigasi dan mulsa organik terhadap tinggi tanaman nanas 6 BST.

\begin{tabular}{|c|c|c|c|c|c|}
\hline \multirow[b]{2}{*}{ Muls a Organik } & \multicolumn{5}{|c|}{ Lama Irig asi } \\
\hline & $\mathrm{I}_{0}$ & $\mathrm{I}_{1}$ & $\mathrm{I}_{2}$ & $\mathrm{I}_{3}$ & $\mathrm{I}_{4}$ \\
\hline & \multicolumn{5}{|c|}{ - } \\
\hline $\mathrm{M}_{0}$ & $66,67 \mathrm{a}$ & $68,39 \mathrm{a}$ & $71,38 \mathrm{a}$ & $72,31 \mathrm{a}$ & $78,26 \mathrm{a}$ \\
\hline & A & A & A & $\mathrm{AB}$ & B \\
\hline \multirow[t]{2}{*}{$\mathrm{M}_{1}$} & $68,85 \mathrm{a}$ & $69,76 \mathrm{a}$ & $72,92 \mathrm{a}$ & $74,1 \mathrm{a}$ & $80,39 \mathrm{a}$ \\
\hline & A & A & A & A & B \\
\hline
\end{tabular}

Keterangan: Angka yang diikuti huruf yang sama tidak berbeda nyata menurut uji BNT pada $\alpha_{0,05}$. Huruf kapital dibaca horizontal, dan huruf kecil dibaca vertikal.

Tabel 3. Pengaruh irigasi dan mulsa organik terhadap berat basah nanas 4 BST.

\begin{tabular}{cccccc}
\hline \multirow{2}{*}{ Mulsa Organik } & \multicolumn{5}{c}{ Lama Irigasi } \\
\cline { 2 - 6 } & \multicolumn{1}{c}{$\mathrm{I}_{0}$} & $\mathrm{I}_{1}$ & $\mathrm{I}_{2}$ & $\mathrm{I}_{3}$ & $\mathrm{I}_{4}$ \\
\cline { 2 - 6 } & $366,67 \mathrm{a}$ & $353,33 \mathrm{a}$ & $526,67 \mathrm{a}$ & $443,33 \mathrm{a}$ & $564 \mathrm{a}$ \\
\hline $\mathrm{M}_{0}$ & $\mathrm{~A}$ & $\mathrm{~A}$ & $\mathrm{~A}$ & $\mathrm{BC}$ & $\mathrm{C}$ \\
& $373,33 \mathrm{a}$ & $396,67 \mathrm{a}$ & $506,67 \mathrm{a}$ & $690 \mathrm{~b}$ & $786,67 \mathrm{~b}$ \\
$\mathrm{M}_{1}$ & $\mathrm{~A}$ & $\mathrm{~A}$ & $\mathrm{~B}$ & $\mathrm{C}$ & $\mathrm{C}$ \\
\hline BNT & \multicolumn{5}{c}{100,07} \\
\hline
\end{tabular}

Keterangan: Angka yang diikuti huruf yang sama tidak berbeda nyata menurut uji BNT pada $\alpha_{0,05}$. Huruf kapital dibaca horizontal, dan huruf kecil dibaca vertikal.

Tabel 4. Pengaruh irigasi dan mulsa organik terhadap berat basah tanaman nanas 6 BST

\begin{tabular}{cc}
\hline Perlakuan Mulsa Organik & Rataan $(\mathrm{g})$ \\
\hline $\mathrm{M}_{0}$ & $935,40 \mathrm{a}$ \\
$\mathrm{M}_{1}$ & $1064,5 \mathrm{a}$ \\
\hline BNT & 148 \\
\hline
\end{tabular}

Keterangan: Angka yang diikuti huruf yang sama tidak berbeda nyata menurut uji BNT pada $\alpha_{0,05}$.

menunjukan berat basah tanamannya tidak berbeda nyata, Namun berbeda nyata dengan perlakuan irigasi yang lain. Sedangkan pada petak yang diberi mulsa perlakuan $\mathrm{I}_{4}$ (irigasi 4 bulan) dan $\mathrm{I}_{3}$ (irigasi 3 bulan) tidak berbeda nyata, tetapi berbeda nyata dengan perlakuan irigasi yang lain. Sedangkan pada perlakuan $\mathrm{I}_{4}$ (irigasi 4 bulan) dan $\mathrm{I}_{3}$ (irigasi 3 bulan) pemberian mulsa 50 $\mathrm{t} \mathrm{ha}^{-1}$ berpengaruh terhadap berat basah tanaman dan berbeda nyata. Data pengaruh irigasi dan mulsa organik terhadap berat basah tanaman nanas 6 BST dapat dilihat pada Tabel 4. Interaksi antara irigasi dengan mulsa pada perlakuan $\mathrm{I}_{4} \mathrm{M}_{1}$ menunjukan berat basah tertinggi $(786,67$ gram) dan terendah pada perlakuan $\mathrm{I}_{1} \mathrm{M}_{0}(353,33 \mathrm{~g})$, hal ini terjadi karena pada perlakuan $\mathrm{I}_{4} \mathrm{M}_{1}$ kebutuhan air bagi tanaman selalu tercukupi hingga akhir perlakuan sehingga tanaman dapat tumbuh dengan optimal, sedangkan pada perlakuan $\mathrm{I}_{1} \mathrm{M}_{0}$ mengalami cekaman kekeringan setalah satu bulan diirigasi hingga akhir perlakuan hal tersebut membuat tanaman tumbuh secara lambat sehingga berat basah tanamannya rendah. Berdasarkan analisis ragam berat basah tanaman 6 BST dipengaruhi oleh faktor perlakuan mulsa $50 \mathrm{t} \mathrm{ha}^{-1}$. Berat basah 6 BST pada perlakuan yang diberi mulsa lebih tinggi $(1064,5 \mathrm{~g})$ dibandingkan perlakuan yang tidak diberi mulsa (935,40 g), Namun berdasarkan uji BNT tidak berbeda nyata.

Nanas secara alami merupakan tanaman yang tahan terhadap kekeringan (Xerofit) karena nanas termasuk jenis tanaman crassulacean acid metabolism (CAM), yaitu tanaman yang membuka stomata pada malam hari untuk menyerap $\mathrm{CO}_{2}$ dan menutup stomata pada siang hari. Hal ini akan mengurangi lajunya transpirasi. Nanas memerlukan sinar matahari yang cukup untuk pertumbuhan. Kondisi berawan pada musim hujan menyebabkan pertumbuhannya terhambat, 
buah menjadi kecil, kualitas buah menurun dan kadar gula menjadi berkurang. Sebaliknya bila sinar matahari terlalu banyak maka tanaman akan terbakar dan buah cepat masak (Coronel dan Verheij, 1997 dalam Gunawan, 2007). Sehingga saat memasuki musim hujan dan banyak tersedia air maka pemulihan keragaan tanaman akan cepat.

Berdasarkan penelitian Nurkholiq (2008), stres air dapat menurukan bobot buah melon $9,49 \%$ pada perlakuan stres air fase vegetatif, $16,05 \%$ pada perlakuan stres air pada fase pembentukan bunga dan $12,85 \%$ pada perlakuan stres air pada fase pengisian buah. Selain itu perlakuan defisit irigasi mempercepat pembungaan, menurunkan diameter buah dan mengurangi hasil buah jeruk (Perez, et al., 2008). Dengan demikian berdasarkan penelitian Nurkholiq (2008) dan Perez, et al. (2008), dimungkinkan cekaman kekeringan akan lebih berpengaruh terhadap proses pembungaan dan kualitas buah nanas.

\section{KESIMPULAN}

Dari penelitian ini maka dapat disimpulkan bahwa tinggi tanaman nanas 6 BST yang diirigasi 4 bulan baik yang tidak diapalikasi mulsa maupun yang diaplikasi mulsa tidak berbeda nyata. Berat basah tanaman 4 BST yang diirigasi 4 bulan bermulsa tidak berbeda nyata dengan diirigasi 4 bulan tanpa mulsa dan irigasi 3 tanpa mulsa dan terjadi pemulihan kergaan tanaman nanas setelah memasuki musim hujan terutama berat basah tanaman.

\section{DAFTAR PUSTAKA}

Biro Pusat statistik. 2012. Nanas. http://bps.go.id. Diakses pada tanggal 3 Agustus 2012.

Ferraris, R. 1992. Seedbed factor affecting establishment of summer crops in a vertisol. Journal of Soil Science and Tillage Research. Vol. 23 (12).1-25.
Gunawan, E. 2007. Kajian pertumbuhan dan produksi nenas pada lahan Gambut dan lahan Aluvial di Kalimantan Barat. Tesis. Pascasarjana. IPB. Bogor.

Hutasoit, D.S.N.P.S. 2006. Pengaruh media tanam dan anti transpirasi selama pengangkutan terhadap daya tahan bibit manggis. Skripsi. IPB. Bogor.

Komariah, K. Ito, M. Senge, J.T. Adomako, dan Afandi. 2008. The influences of organik munches on soil moisture content and temperature. Journal of Rainwater Catchment System. Vol.14 (1). 1-8.

Nasution, O.B. 2000. Pemberian terracottem dan bahan organik pada tahun kelima serta pemberian mulsa terhadap sifat fisika tanah, pertumbuhan dan produksi kedelai pada Alfisol Jonggol. Skripsi. IPB. Bogor.

Nurkholiq, A. W. 2008. Respon pertumbuhan dan perkembangan melon (cucumis melo) terhadap stres air. Skripsi. IPB. Bogor.

Perez, J. G., P. Romero, J. M. Navarro, P. Botia. 2008. Response of sweet orange cv 'Lane Late' to deficit- irrigation strategy in two rootstocks. II: flowering, fruit growth, yield, and fruit quality. Journal of Irrigation Science. Vol. 26 (5). 19-29.

Surater, T., J. Wiroatmodjo, S. Solahuddin., L.I. Nasution, M. A. Nur, dan A. Bey. 1986. Pengaruh tumpang sari jagung dan pemberian mulsa terhadap produksi tanaman kentang. Buletin Agronomi. Vol. 17 (2). 1- 6. 